\title{
An experimental study of shear strength of gas-hydrate-bearing core samples
}

\author{
Zhang Weidong*, Ma Qingtao, Wang Ruihe and Ren Shaoran \\ School of Petroleum Engineering, China University of Petroleum, Dongying, Shandong 257061, China \\ (C) China University of Petroleum (Beijing) and Springer-Verlag Berlin Heidelberg 2011
}

\begin{abstract}
The shear strength of gas-hydrate-bearing reservoirs is one of the most important parameters used to study mechanical properties of gas-hydrate-bearing reservoirs. The shear strength of gas-hydratebearing reservoirs changes with filling and cementation of gas hydrates, which will affect the wellbore and reservoir stability. Traditional shear tests could not be conducted on gas-hydrate-bearing core samples because the gas hydrates exist under a limited range of temperature and pressure conditions. This paper describes a novel shear apparatus for studying shear strength of gas-hydrate-bearing core samples under original reservoir conditions. The preparation of gas-hydrate-bearing core samples and subsequent shear tests are done in the same cell. Cohesion and internal friction angle of the core samples with different saturations of gas hydrates were measured with the apparatus. The effect of gas hydrates on the shear strength of reservoirs was quantitatively analyzed. This provides a foundation for studying wellbore and reservoir stability of gas-hydrate-bearing reservoirs.
\end{abstract}

Key words: Natural gas hydrate, reservoir, experimental apparatus, shear test, internal cohesion, internal friction angle

\section{Introduction}

Shear strength is one of the most important mechanical parameters of reservoir rocks in analyzing wellbore stability. However, it is difficult to measure the shear strength of gashydrate-bearing core samples with commonly-used shear apparatus due to the presence of gas hydrates, which form when natural gas molecules and water come into contact at low temperature and high pressure (Tan et al, 2005).

To solve this problem, Wu et al (1997) developed a Hoek triaxial cell for gas hydrate-bearing deposits. This device could be used to measure mechanical properties and failure mechanisms of sediments containing gas hydrates under confining pressures. However, its core cell is so small that the gas hydrates are not evenly distributed in the artificial core samples, leading to large errors in shear strength. Clayton and Priest (2005) built a resonant column apparatus to synthesize methane hydrate-bearing sediments and to measure their shear strength based the original triaxial shear apparatus.

After conducting triaxial shear tests on original hydrate deposits from the Malik 2L-38 well, Mackenzie Delta, Northwest Territories, Winters et al (2004) proposed that the shear strength of sediments containing gas hydrates increased with an increase in gas hydrate saturation. Researchers at the Georgia Institute of Technology tested the Poisson ratio, shear strength, and other mechanical parameters of sands, clays,

*Corresponding author. email: wdzhang@upc.edu.cn

Received October 9, 2010 and quartz powders containing gas hydrates in the laboratory. Moreover they studied the cohesion and friction angle of quartz powders when the saturations of gas hydrates were $50 \%$ and 0 .

In this study, we developed a new experimental setup to investigate the properties of gas-hydrate-bearing core samples under high pressure and low temperature.

\section{Experimental}

\subsection{Experimental apparatus}

The shear apparatus shown in Fig. 1 was used for gas hydrate formation followed by shear testing. In the same cell, the core samples containing gas hydrates were formed and then shear tests were conducted, avoiding inconveniences involved in core preparation and installation in shear tests.

The main component of this device was the shear unit installed in the pressure cell and the shear unit consisted of the shear cell and piston mechanisms. The shear cell had two chambers, and the connection was sealed with an annular piston. The upper cell was equipped with a piston for compacting and a water inlet, a transverse piston mechanism was installed on the middle of the upper cell. Piston mechanisms were installed on both side of the lower cell. The lower cell had a gas inlet and a water outlet. All piston mechanisms were connected to the high pressure pump by hydraulic lines. The lower shear cell was fixed on the bottom of the high pressure cell, and the upper one was connected to the top of the high pressure cell. A circulating water bath with an 


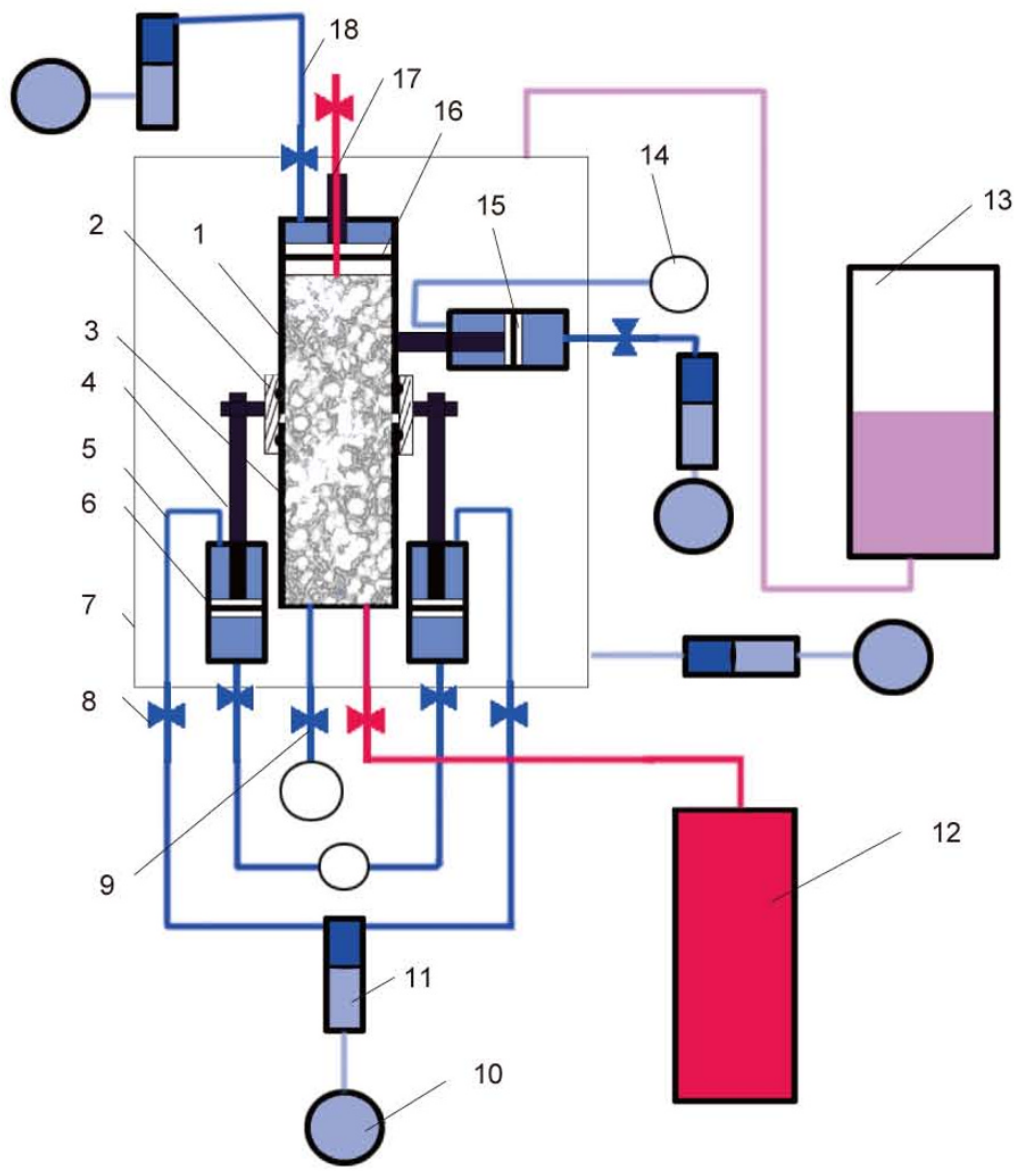

Fig. 1 Schematic of a shear apparatus for hydrate-bearing core samples (Yin et al, 2008) 1-Upper shear cell; 2-Annular piston; 3-Lower shear cell; 4-Rigid rod; 5-High pressure pipeline; 6-Piston cylinder; 7-Pressure cell; 8-Valve; 9-Entrance to the shear cell; 10-High pressure pump; 11-Piston vessel; 12-Methane cylinder; 13-High pressure air container; 14-Back-pressure valve;

15-Transverse piston; 16-Compacting piston; 17-Intake line; 18-High pressure line

insulation layer was used to ensure the system remained at low temperatures. Fig. 2 shows the equipment in the laboratory.

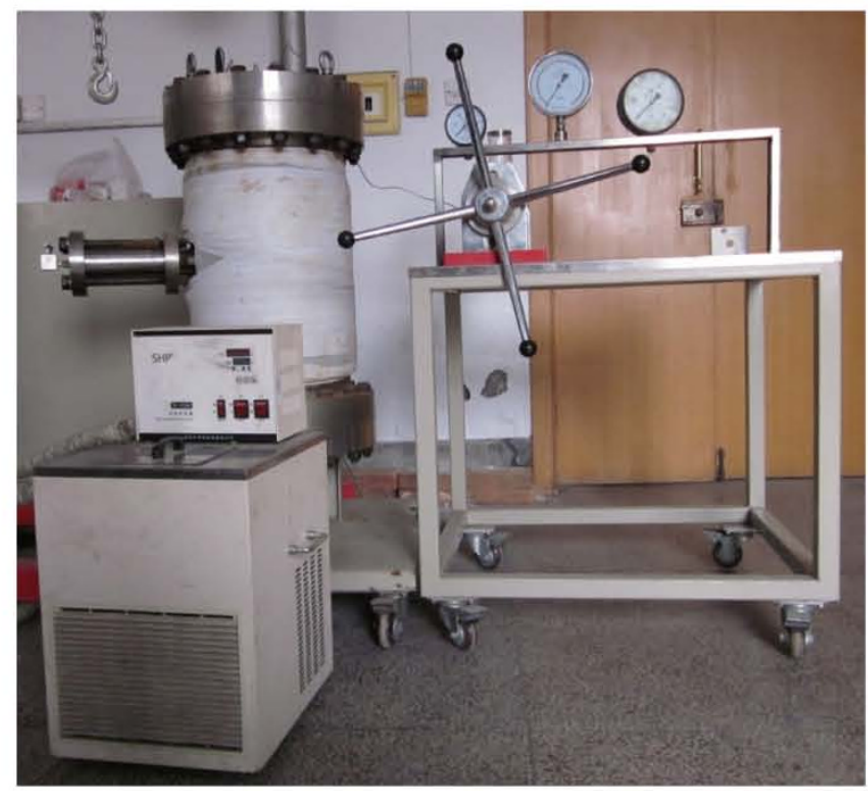

Fig. 2 The experimental shear device for gas hydrate-bearing core samples

\subsection{Test procedures}

Methane (99.99\% purity), quartz sand of 20-40 mesh, and distilled water were used to prepare gas hydrate-bearing core samples. According to the data on core samples containing hydrates, the hydrate-bearing reservoir matrix had the same density as quartz sand (Tinivella, 1999).

The test procedures are as follows.

Preparation of gas hydrates in porous medium 1) Wash both the shear cell and the quartz sand with distilled water twice and air dry them before use. 2) Put the dry quartz sand into the upper and lower shear cells. 3) Adjust the shear cell to make sure the shear planes of the upper and lower cells contact completely. 4) Lift the annular piston up to the proper position to seal the shear cells. 5) Install the high pressure cell and inject water into it. 6) Control the high-pressure cell temperature at $3{ }^{\circ} \mathrm{C}$ with the circulating water bath. 7) Use the hand pump to compact quartz sand. 8) Withdraw all air out of the shear cell with a vacuum pump (evacuate the cell). 9) Inject distilled water into the cell until water overflows from the top end. 10) Inject methane and collect water flowing from the shear cell and measure its volume $V$. 11) Close the bottom valve when a bubble forms and then inject the remaining methane into the shear cell. 12) Inject distilled 
water from the bottom of the shear cell until the pressure reaches $7 \mathrm{MPa}$. 13) The pressure in the high pressure cell will decline as the reaction goes on. It is necessary to refill the distilled water at frequent intervals to maintain pressure at $7 \mathrm{MPa}$. 14) Repeat Step 13 until the pressure is constant. The methane injected into the cell will completely react with water to form hydrates.

Shear test 1) Apply the confining pressure of $7 \mathrm{MPa}$ to the shear cell, which equals the pressure in the high-pressure cell. 2) Push the annular piston down to shear the core sample. 3) Record the pressure changes. The pressure will rise slowly at the beginning and then decline sharply when the core sample is sheared. 4) Record the pressure $P$ when the shear failure happens in the shear cell. The lateral pushing force $F$ is equal to the product of the pressure $P$ times the area of the lateral piston $A$. The ratio of $F$ to $A$ is the shear strength of the hydrate-bearing core sample.

\subsection{Determination of gas hydrate saturation} 1998):

The hydration reaction of methane is given by (Sloan,

$$
\mathrm{CH}_{4}(\mathrm{~g})+n_{\text {hyd }} \mathrm{H}_{2} \mathrm{O}(\mathrm{l}) \longleftrightarrow \mathrm{CH}_{4} \cdot n_{\text {hyd }} \mathrm{H}_{2} \mathrm{O}(\mathrm{s})
$$

where $n_{\text {hyd }}$ is the hydration number, the molar ratio of water reacting with methane, $n_{\text {hyd }}=5.75$ in this case.

After the temperature and pressure of the core cell are stabilized, all methane injected into the cell is assumed to react completely with water. There are only gas hydrates and water remaining in the artificial core samples. Then the gas hydrate saturation can be calculated as follows (Ren et al, 2010):

$$
S_{\mathrm{h}}=\frac{P_{\mathrm{CH}_{4}} V_{\mathrm{CH}_{4}} M_{\mathrm{h}}}{Z R T V_{\text {pore }} \rho_{\mathrm{h}}}
$$

where $S_{\mathrm{h}}$ is the gas hydrate saturation; $V_{\mathrm{CH}_{4}}$ and $P_{\mathrm{CH}_{4}}$ are the injection volume and pressure of methane, $\mathrm{L} ; M_{\mathrm{h}}$ is the molar mass of methane hydrates, $\mathrm{g} / \mathrm{mol} ; R$ is the gas constant, $R=8.31 \mathrm{~J} /(\mathrm{mol} \cdot \mathrm{K}) ; V_{\text {pore }}$ is the pore volume, $\mathrm{L} ; Z$ is the gas compressibility factor; $\rho_{\mathrm{h}}$ is the gas hydrates density, $\rho_{\mathrm{h}}=0.91 \mathrm{~g} / \mathrm{cm}^{3}$.

\subsection{Analysis of shearing process}

In the process of gas hydrate formation, the injection pressure of methane was kept at 3.7 $\mathrm{MPa}$ and the methane injection volume was $2 \mathrm{~L}$. The gas hydrate saturation was calculated to be $55 \%$ from Eq. (2). In the shearing process, the back pressure was kept at $11 \mathrm{MPa}$ to insure the confining pressure higher than $11 \mathrm{MPa}$. At the early stage, the shear piston did not contact with the shear cell and the data were recorded every 5 seconds. At the later stage, the piston pushed down into the shear cell and the data were recorded every 2 seconds as the pressure changed quickly. The experimental results are shown in Table 1.

\subsubsection{Shear pump pressure}

As shown in Fig. 3, the shear pump was pressurized

\begin{tabular}{|c|c|c|c|c|}
\hline $\begin{array}{c}\text { Time } \\
\mathrm{s}\end{array}$ & $\begin{array}{c}\text { Pressure in } \\
\text { the shear cell } \\
\mathrm{MPa}\end{array}$ & $\begin{array}{c}\text { Confining } \\
\text { pressure } \\
\mathrm{MPa}\end{array}$ & $\begin{array}{c}\text { Shear pump } \\
\text { pressure } \\
\mathrm{MPa}\end{array}$ & $\begin{array}{c}\text { Temperature } \\
{ }^{\circ} \mathrm{C}\end{array}$ \\
\hline 0 & 10.7 & 11.0 & 6.00 & 3.9 \\
\hline 5 & 10.7 & 11.0 & 6.13 & 3.9 \\
\hline 10 & 10.8 & 11.1 & 6.22 & 3.9 \\
\hline 15 & 10.8 & 11.2 & 6.28 & 3.9 \\
\hline 20 & 10.8 & 11.1 & 6.32 & 3.9 \\
\hline 25 & 10.8 & 11.1 & 6.32 & 3.9 \\
\hline 30 & 10.8 & 11.1 & 6.32 & 3.9 \\
\hline 35 & 10.7 & 11.2 & 6.32 & 3.9 \\
\hline 40 & 10.8 & 11.1 & 6.32 & 4.0 \\
\hline 45 & 10.9 & 11.2 & 6.32 & 4.0 \\
\hline 50 & 10.9 & 11.2 & 6.32 & 4.0 \\
\hline 52 & 10.9 & 11.2 & 6.32 & 4.0 \\
\hline 54 & 11.0 & 11.1 & 6.40 & 4.0 \\
\hline 56 & 11.0 & 11.1 & 6.45 & 3.9 \\
\hline 58 & 11.0 & 11.1 & 6.58 & 3.7 \\
\hline 60 & 11.0 & 11.0 & 6.78 & 3.5 \\
\hline 62 & 11.0 & 11.0 & 6.90 & 3.4 \\
\hline 64 & 11.0 & 11.0 & 6.44 & 3.4 \\
\hline 66 & 11.0 & 11.0 & 6.32 & 3.4 \\
\hline 68 & 11.0 & 11.0 & 6.32 & 3.4 \\
\hline 70 & 11.0 & 11 & 6.32 & 3.4 \\
\hline
\end{tabular}

Table 1 Data acquired in the shearing process

during 0-20 s, and the shear piston began to move when the pressure reached 6.32 $\mathrm{MPa}$, i.e. starting pressure under experimental conditions. The shear piston began to move upwards to push the upper shear cell at the time of $54 \mathrm{~s}$, and the shear failure occurred during 54-62 s for gas-hydratebearing core samples. The maximum shear pressure was $6.9 \mathrm{MPa}$. It was at the pressure release stage after $62 \mathrm{~s}$, and the pressure was back to $6.32 \mathrm{MPa}$ at the end. So the shear strength was $0.58 \mathrm{MPa}(6.90-6.32)$ under the test conditions.

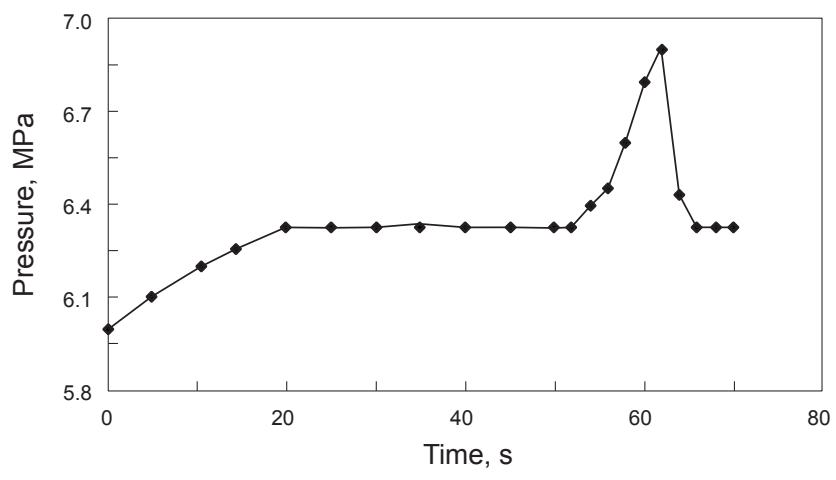

Fig. 3 Curve of pump pressure vs. time in the shearing process 


\subsubsection{Shear cell temperature}

As Fig. 4 shows, the temperature of the high-pressure cell increased slightly due to the interference of external temperature in the piston compression process. The temperature declined significantly at $58 \mathrm{~s}$, eventually to 3.4 ${ }^{\circ} \mathrm{C}$. This is because the lower and upper shear cells were disconnected and the gas hydrates absorbed heat and then partially dissociated into gas and water (Sun et al, 2002).

\section{Result analyses}

Shear test data on gas-hydrate-bearing core samples are shown in Table 2. The shear strength is the cohesion of hydrate-bearing samples when the axial pressure is 0 . The internal friction angle of hydrate-bearing core samples was calculated according to the Mohr-Coulomb criterion and shear forces at different axial pressures (Huang et al, 1999).

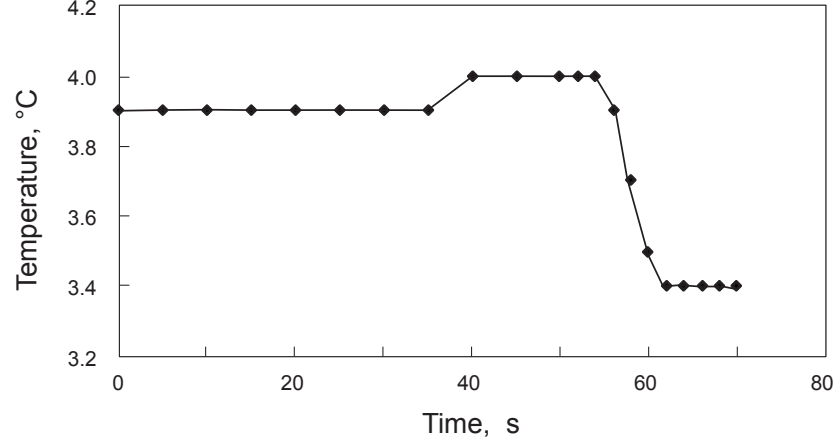

Fig. 4 Curve of temperature vs. time in the shearing process

\subsection{Cohesion}

Fig. 5 shows that the cohesion of artificial hydrate-bearing core samples increased quickly with increasing hydrate

Table 2 Shear test data on core samples containing different contents of gas hydrates

\begin{tabular}{|c|c|c|c|c|c|c|}
\hline No. & $\begin{array}{l}\text { Gas hydrate } \\
\text { saturation } \\
\%\end{array}$ & $\begin{array}{c}\text { Gas hydrate } \\
\text { formation time } \\
\mathrm{h}\end{array}$ & $\begin{array}{c}\text { Gas hydrate formation } \\
\text { pressure } \\
\mathrm{MPa}\end{array}$ & $\begin{array}{l}\text { Temperature } \\
{ }^{\circ} \mathrm{C}\end{array}$ & $\begin{array}{c}\text { Axial pressure } \\
\mathrm{MPa}\end{array}$ & $\begin{array}{c}\text { Shear force } \\
\text { MPa }\end{array}$ \\
\hline \multirow{3}{*}{1} & \multirow{3}{*}{0} & \multirow{3}{*}{158} & \multirow{3}{*}{11.1} & \multirow{3}{*}{3.7} & 0 & 0 \\
\hline & & & & & 1.0 & 0.29 \\
\hline & & & & & 2.0 & 0.56 \\
\hline \multirow{3}{*}{2} & \multirow{3}{*}{5} & \multirow{3}{*}{162} & \multirow{3}{*}{11.0} & \multirow{3}{*}{3.7} & 0 & 0.05 \\
\hline & & & & & 1.0 & 0.32 \\
\hline & & & & & 2.0 & 0.60 \\
\hline \multirow{3}{*}{3} & \multirow{3}{*}{15} & \multirow{3}{*}{160} & \multirow{3}{*}{11.3} & \multirow{3}{*}{3.7} & 0 & 0.14 \\
\hline & & & & & 1.0 & 0.45 \\
\hline & & & & & 2.0 & 0.78 \\
\hline \multirow{3}{*}{4} & \multirow{3}{*}{25} & \multirow{3}{*}{160} & \multirow{3}{*}{11.2} & \multirow{3}{*}{3.5} & 0 & 0.20 \\
\hline & & & & & 1.0 & 0.55 \\
\hline & & & & & 2.0 & 0.9 \\
\hline \multirow{3}{*}{5} & \multirow{3}{*}{35} & \multirow{3}{*}{159} & \multirow{3}{*}{11.0} & \multirow{3}{*}{3.5} & 0 & 0.28 \\
\hline & & & & & 1.0 & 0.72 \\
\hline & & & & & 2.0 & 1.13 \\
\hline \multirow{3}{*}{6} & \multirow{3}{*}{45} & \multirow{3}{*}{160} & \multirow{3}{*}{11.0} & \multirow{3}{*}{3.5} & 0 & 0.41 \\
\hline & & & & & 1.0 & 0.95 \\
\hline & & & & & 2.0 & 1.47 \\
\hline \multirow{3}{*}{7} & \multirow{3}{*}{50} & \multirow{3}{*}{161} & & & 0 & 0.52 \\
\hline & & & 11.2 & 3.3 & 1.0 & 1.06 \\
\hline & & & & & 2.0 & 1.62 \\
\hline & & & & & 0 & 0.55 \\
\hline 8 & 55 & 161 & 11.1 & 3.3 & 1.0 & 1.22 \\
\hline & & & & & 2.0 & 1.85 \\
\hline
\end{tabular}


saturation when the saturation was less than $55 \%$. This is because that gas hydrates were formed in the porous medium in which water was present in excess. More water would fill the remaining pores when the hydrate saturation was low, and then affected the gas hydrate cementation. Water in the remaining pores decreased as the hydrate saturation increased, therefore the gas hydrate cementation would increase.

The correlation between the cohesion angle and hydrate saturation for artificial core samples containing gas hydrates can be expressed as follows:

$$
c=0.00008 S_{\mathrm{h}}{ }^{2}+0.0057 S_{\mathrm{h}}+0.0137 \quad R^{2}=0.991
$$

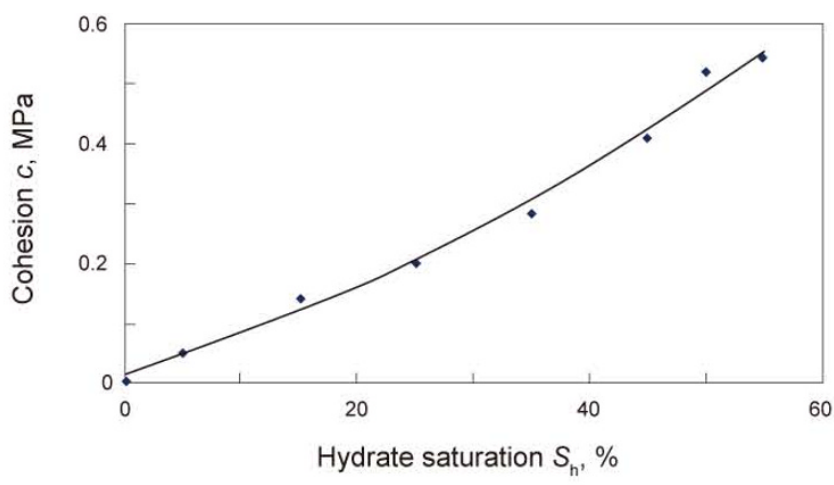

Fig. 5 Relationship between the cohesion and hydrate saturation

\subsection{Internal friction angle}

Fig. 6 shows that the internal friction angle of hydratebearing core samples increased with hydrate saturation when the saturation was less than $55 \%$. The reason is due to water filled in the porous medium. Chen et al (1998) determined the internal friction angle of man-made permafrost to be $8.12^{\circ}$ with the triaxial test; Yue et al (1994) determined the angle of sea ice to be $39^{\circ}$ with the lateral restraint shear strength test; and Masui et al (2007) performed triaxial tests on four natural gas hydrate-bearing sediments drilled in the South Japan Sea and several artificial hydrate-bearing sediments and determined the average internal friction angle to be $31^{\circ}$ at $50 \%$ hydrate saturation (Yun, 2005). It can be seen that the internal friction angle of hydrate-bearing sand packs is between permafrost and sea ice.

The correlation between the internal friction angle and hydrate saturation for artificial core samples containing gas hydrates can be expressed as follows:

$$
\phi=0.0033 S_{\mathrm{h}}{ }^{2}+0.0978 S_{\mathrm{h}}+15.941 \quad R^{2}=0.991
$$

\subsection{Application}

We can use the Mohr-Coulomb criterion to evaluate the wellbore stability during drilling through the hydrate-bearing reservoirs (Hoek and Brown, 1980)

$$
\tau=c+(\sigma-P) \operatorname{tg} \phi
$$

where $\tau$ is the shear strength; $c$ is the cohesion of hydratebearing reservoirs; $\sigma$ is the normal stress; $P_{\mathrm{p}}$ is the porosity

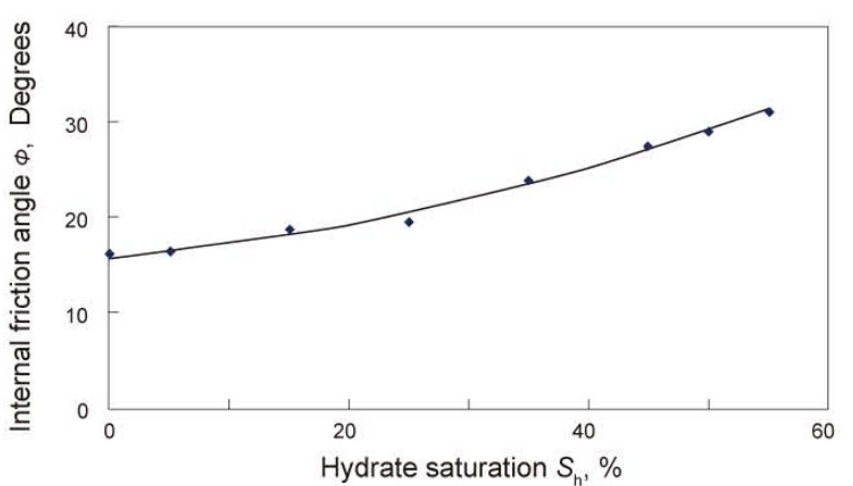

Fig. 6 Relationship between internal friction angle and hydrate saturation

pressure; $\phi$ is the internal friction angle.

The shear failure curve of hydrate-bearing reservoirs in $\sigma-\tau$ coordinates can be obtained by $c$ and $\phi$, as Fig. 7 shows. The area on the inside of the shear failure curve is stable.

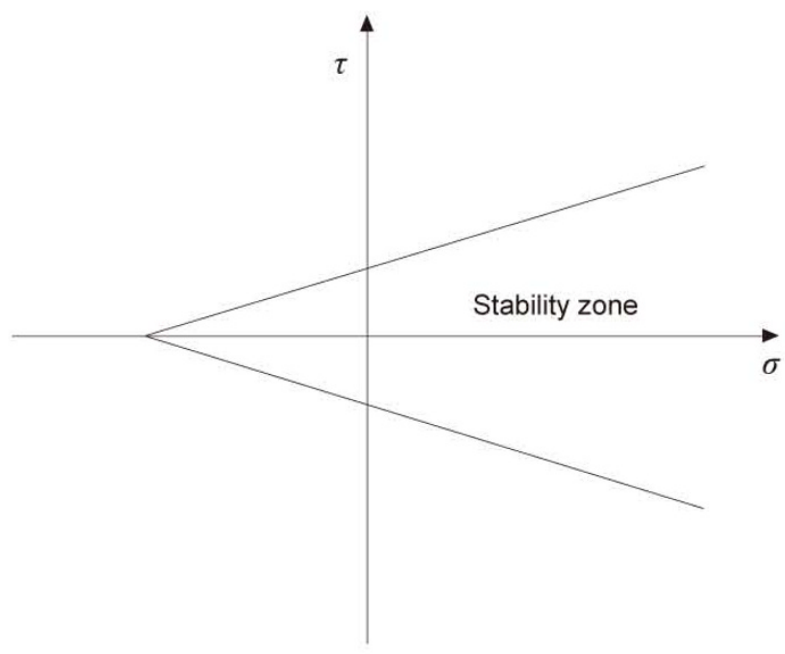

Fig. 7 Shear failure curve of hydrate-bearing reservoirs

\section{Conclusions}

1) A novel shear apparatus was built to study the shear strength of gas-hydrate-bearing core samples. In this apparatus, the shear cell consists of upper and lower chambers sealed with an annular piston. This allows the preparation of the gas hydrate-bearing core samples and the follow-up shear testing to be conducted in the same shear cell.

2) If the hydrate saturation was less than $55 \%$, the cohesion of the hydrate-bearing core samples increased quickly when the hydrate saturation increased. Cementation between gas hydrates and quartz sand is responsible for the increase in cohesion. The internal friction angle exhibited the same trend. The internal friction angle of hydrate-bearing core samples is between that of permafrost and sea ice.

3) The relationship between shear strength and saturation was detevmined, but it can not reflect the variation of shear strength during phase change of hydrates, because the shear strength will change when the water saturation of reservoirs changes during hydrates phase change. 


\section{Acknowledgements}

The authors are grateful for financial support from "Preliminary Research on natural gas hydrates production" from SINOPEC (No. P06070).

\section{References}

Chen X S, Wang C X and Wu C Y. Research on triaxial shear strength principle of typical artificially frozen soil. Mine Construction Technology. 1998. 19(4): 2-4 (in Chinese)

Clayton C R I and Priest A I. The effects of disseminated methane hydrate on the dynamic stiffness and damping of a sand. Geotechnique. 2005. 55(6): 423-434

Hoek E and Brown E. Empirical strength criterion for rock masses. Journal of the Geotechnical Engineering Division. 1980. 106(GT9): 989-1013

Huang R Z, Deng J G and Chen M. Calculation model of borehole collapse and fracturing pressure. Beijing: Petroleum Industry Press. 1999. 104-112 (in Chinese)

Masui A, Haneda H, Ogata Y, et al. Mechanical properties of sandy sediment containing marine gas hydrates in deep sea offshore Japan. In: Proceedings of the 17th International Offshore and Polar Engineering, Ocean Mining Symposium, Lisbon, Portugal. July 1-6, 2007. 53-56

Ren S R, Shang X S and Zhang W D. A instrument for measuring the physical properties of hydrate-bearing reservoirs. Chinese Patent: 201020127827.6 (in Chinese)
Sloan Jr. E D. Clathrate hydrates of natural gases. Marcel Dekker Inc. New York. 1998. 15-18

Sun Z G, Fan S S, Guo K H, et al. Determination of dissociation heat of natural gas hydrates. Journal of Instrumental Analysis. 2002. 21(3): 7-9 (in Chinese)

Tan C P, Freij-Ayoub F, Clennell M B, et al. Managing wellbore instability risk in gas-hydrate-bearing sediments. Paper SPE 92960 presented at Asia Pacific Oil \& Gas Conference and Exhibition, 5-7 April 2005, Jakarta, Indonesia

Tinivella U. A method for estimating gas hydrate and free gas concentrations in marine sediments. Bollettino di Geofisca Teorica Applicata. 1999. 40. 19-30

Winters W J, Pecher I A, Waite1 W F, et al. Physical properties and rock physics models of sediment containing natural and laboratoryformed methane gas hydrate. American Mineralogist. 2004. 89: 1221-1227

Wu B, Tan C P and Aoki T. Specially designed techniques for conducting consolidated undrained triaxial tests on low permeability shales. International Journal of Rock Mechanics and Mining Science. 1997. 34: 3-4

Yin Y W, Zhang W D, Wang R H, et al. A new type of hydrates shear strength apparatus. Chinese Patent: ZL 200820027803. 6 (in Chinese)

Yue Q J, Zhou X A and Shen W. Confined shear test on sea ice. Journal of Glaciology and Geocryology. 1994. 16(1): 77-78 (in Chinese)

Yun T S. Mechanical and thermal study of hydrate bearing sediments. In: Partial Fulfillment of the Requirements for the Degree of Doctor of Philosophy in Civil and Environmental Engineering. May 24, 2005

(Edited by Sun Yanhua) 